\title{
PENGARUH PENERAPAN MODEL PEMBELAJARAN PROJECT BASED LEARNING (PjBL) DENGAN BERBANTUAN SOFTWARE SPSS TERHADAP MOTIVASI DAN PEMAHAMAN STATISTIKA
}

\author{
Heri Herwanto \\ Teknik Informatika Universitas Kuningan \\ Jl Cut Nyak Dien No 36 A Cijoho Kabupaten Kuningan \\ Email : hery210@gmail.com
}

\begin{abstract}
Abstrak
Penelitian yang berjudul "Pengaruh Penerapan Model Pembelajaran Project Based Learning (PjBL) dengan Berbantuan software SPSS terhadap Motivasi dan Pemahaman Statistika" dilakukan pada mahasiswa semester dua program studi Teknik Informatika Fakultas ilmu komputer Universitas Kuningan. Penelitian bertujuan untuk menganalisis pengaruh dari penerapan model pembelajaran Project Based Learning dampaknya terhadap motivasi dan pemahaman statistika mahasiswa. Berdasarkan hasil penelitian diperoleh fakta bahwa besarnya pengaruh penerapan model pembelajaran Project Based Learning terhadap motivasi dan pemahaman statistika adalah sigifikan dan tanggapan mahasiswa terhadap penerapan model pembelajaran Project Based Learning dengan berbantuan software SPSS adalah positif.
\end{abstract}

Kata Kunci : Model Pembelajaran Project Based Learning, Software SPSS, Motivasi dan Pemahaman Statistika

\section{Pendahuluan}

Kualitas pendidikan seseorang dapat diidentifikasi dari proses belajar mengajar yang diimplementasikan dengan berbagai aktivitas dan kegiatan sehingga setelah melalui proses tersebut peserta didik/ mahasiswa memperoleh nilai tambah pengetahuan dan keterampilan yang bermanfaat bagi dirinya dan lingkungan sekitar. Mata kuliah matematika di fakultas ilmu komputer merupakan mata kuliah wajib yang harus ditempuh oleh setiap mahasiswa pada semua program studi, salah satu cabang dari matakuliah matematika adalah statistika. Matakuliah statistika merupakan ilmu terapan yang berperan dalam melengkapi matakuliah ilmu komputer, dengan adanya statistika mahasiswa dapat menguji kualitas program yang telah dibuat melalui analisis uji statistik sehingga mahasiswa dapat mendeteksi kekurangan dan kelebihan program yang telah dibuat. Tetapi fakta yang terjadi, masih banyak mahasiswa yang belum mengetahui peranan statistika dalam ilmu komputer, mahasiswa masih menganggap statistika merupakan matakuliah yang sulit untuk dipahami, sehingga dalam proses pembelajaran mahasiswa kurang memiliki motivasi untuk bisa memahami statistika.

Berdasarkan data, fakta dan masalah yang telah dipaparkan, maka penulis tertarik untuk melakukan penelitian dengan judul "Pengaruh Penerapan Model Pembelajaran Project Based Learning dengan berbantuan Software SPSS terhadap Motivasi dan Pemahaman Statistika."

Berdasarkan latar belakang masalah diatas, batasan masalah dalam penelitian ini adalah penerapan model pembelajaran Project Based Learning, Software SPSS, motivasi belajar mahasiswa, dan pemahaman statistika.

Rumusan masalah dalam penelitian ini adalah:

1. Adakah pengaruh penerapan model pembelajaran Project Based Learning dengan berbantuan Software SPSS terhadap motivasi belajar mahasiswa?

2. Adakah pengaruh penerapan model pembelajaran Project Based Learning dengan berbantuan Software SPSS terhadap pemahaman statistika?

3. Adakah Hubungan motivasi terhadap pemahaman statistika? 
4. Bagaimana tanggapan mahasiswa terhadap penerapan model pembelajaran Project based Learning dengan berbantuan Software SPSS?

Adapun tujuan penelitian ini adalah sebagai berikut :

1. Untuk menganalisis pengaruh penerapan model pembelajaran Project Based Learning dengan berbantuan Software SPSS terhadap motivasi belajar mahasiswa.

2. Untuk menganalisis pengaruh penerapan model pembelajaran Project Based Learning dengan berbantuan Software SPSS terhadap pemahaman statistika.

3. Untuk menganalisis hubungan motivasi terhadap pemahaman statistika.

4. Untuk menganalisis tanggapan mahasiswa terhadap penerapan model pembelajaran Project based Learning dengan berbantuan Software SPSS.

Adapun manfaat dari penelitian ini adalah sebagai berikut:

1. Bagi mahasiswa, untuk menambah wawasan pengetahuan dan pemahaman tentang statistika yang dituangkan melalui sebuah project dengan berbantuan Software SPSS.

2. Bagi dosen, untuk menambah pengalaman dalam pemilihan model pembelajaran

3. Bagi lembaga, untuk menambah referensi dalam pemilihan dan alternatif mengenai pemanfaatan media pembelajaran sebagai sumber belajar untuk meningkatkan prestasi mahasiswa dalam bidang bahasa inggris dan IT.

Dalam upaya menghindari perbedaan interpretasi terhadap pokok permasalahan yang akan dikaji dalam penelitian ini, berikut dikemukakan definisi dari setiap variabel penelitian yaitu sebagai berikut :

\section{a. Model Pembelajaran Project Based Learning}

Pembelajaran Berbasis Proyek (Project Based Learning/PjBL) adalah metoda pembelajaran yang menggunakan proyek/kegiatan sebagai media. Peserta didik melakukan eksplorasi, penilaian, interpretasi, sintesis, dan informasi untuk menghasilkan berbagai bentuk hasil belajar. Pembelajaran Berbasis Proyek merupakan metode belajar yang menggunakan masalah sebagai langkah awal dalam mengumpulkan dan mengintegrasikan pengetahuan baru berdasarkan pengalamannya dalam beraktifitas secara nyata. (Kemendikbud, 2013)

Pelaksanaan PjBL terbagi menjadi enam langkah (Widyantini, Th, 2014) sebagai berikut:

a. Penentuan Pertanyan Mendasar (Start With the Essential Question)

Pembelajaran dimulai dengan pertanyaan yang dapat memberi penugasan kepada siswa dalam melakukan suatu aktivitas.

b. Mendesain Perencanaan Proyek (Design a plan for the Project)

Perencanaan berisi aturan main, pemilihan aktivitas yang dapat mendukung dalam menjawab pertanyaan esensial dengan cara mengintegrasikan berbagai subjek yang mungkin, serta mengetahui alat dan bahan yang dapat diakses untuk membantu penyelesaan proyek

c. Menyusun Jadwal (Create a Scheduel)

Guru dan siswa secara kolaboratif menyusun jadwal aktivitas dalam menyelesaikan proyek.

d. Memonitor Siswa dan Kemajuan Proyek (Monitor the Students and the Progress of the Project)

Monitoring dilakukan dengan cara memfasilitasi siswa pada setiap proses. Dengan kata lain guru berperan sebagai mentor bagi aktivitas siswa

e. Menguji Hasil (Assess the Outcome)

Penilaian dilakukan untuk membantu guru dalam mengukur ketercapaian standar, berperan dalam mengevaluasi kemajuan masing-masing siswa, memberi umpan balik tentang tingkat pemahaman yang sudah dicapai siswa, membantu guru dalam menyusun strategi pembelajaran berikutnya.

f. Mengevaluasi Pengalaman (Evaluate the Experience) Pada akhir pembelajaran, guru dan siswa melakukan refleksi terhadap aktivitas dan hasil proyek yang sudah dijalankan. 


\section{b. Motivasi Belajar}

Motivasi dan belajar merupakan dua hal yang saling mempengaruhi. Belajar adalah perubahan tingkahlaku secara relativ permanen dan secara potensial terjadi sebagai hasil dari praktik atau penguatan yang dilandasi tujuan untuk mencapai tujuan tertentu. Motivasi belajar dapat timbul karena faktor intrinsik berupa hasrat dan keinginan berhasil dan doronga kebutuhan belajar, harapan akan cita-cita. Sedangkan factor ekstrinsiknya adalah adanya penghargaan. Lingkungan belajar yang konduksif dan kegiatan belajar yang menarik, kegiatan belajar yang menarik harus diciptakan oleh seorang guru, melalui berbagai cara, misalnya dengan metode belajar yang disukai siswa, dengan kedekatan guru dalam pembelajaran dan lain-lain. Hakikat motivasi belajar adalah dorongan internal dan eksternal pada siswa-siswa yang sedang belajar untuk mengadakan perubahan tingkah laku, pada umumnya dengan beberapa indikator yang mendukung. Schunk and Zimmerman (2009: 1) berpendapat: "Among source of motivation the are: interests, self-efficacy, volition, task values, confidence in learning, outcome expectancy and future time perspective". Pendapat di atas menjelaskan motivasi dapat dilihat dari: minat, kemandirian, kemauan, nilai ulangan, kepercayaan diri dalam belajar, orientasi pada hasil, dan pandangan terhadap masa depan.

\section{Pembahasan}

Teknik Pengambilan sampel dilakukan dengan Sampling Purposive yaitu teknik penentuan sampel dengan pertimbangan tertentu (Sugiyono,2009). Sampel diambil dari mahasiswa Program Studi Teknik Inforatika semester dua tahun ajaran 2015/2016 fakultas ilmu komputer Universitas Kuningan sebanyak 30 Orang sebagai kelas eksperimen (PjBL) dengan mempertimbangkan bahwa aktualisasi matematika dalam mata kuliah statistika kurang mendapatkan apresiasi yang positif dari mahasiswa Program Studi Teknik Informatika. Metode yang digunakan dalam penelitian ini adalah metode eksperimen dengan bentuk PreExperimental Design. Dalam desain eksperimen ini tidak adanya variabel kontrol (kelas kontrol) dan tidak dipilih secara random. Dikatakan pre-experimental design karena desain ini belum merupakan eksperimen sungguh - sungguh, karena masih terdapat variabel luar yang ikut berpengaruh terhadap terbentuknya variabel dependen. Jadi, hasil eksperimen yang merupakan variabel dependen itu bukan semata - mata dipengaruhi oleh variabel independen (Sugiyono, 2009:109).

Desain penelitian dengan menggunakan model Pre-Experimental Design dengan bentuk One Group Pretest-Posttest Design mengandung paradigma bahwa terdapat suatu kelompok diberi treatment / perlakuan dan selanjutnya diobservasi hasilnya, akan tetapi sebelum diberi perlakuan terdapat pretest untuk mengetahui kondisi awal. Dengan demikian, hasil perlakuan dapat lebih akurat karena dapat membandingkan dengan keadaan sebelum diberi perlakuan.

Analisis yang digunakan untuk mengetahui Tanggapan mahasiswa terhadap penerapan model Pembelajaran Project Based Learning dengan Berbantuan Software SPSS adalah dengan menggunakan analisis butir pernyataan dengan menjumlah total semua skor tanggapan pada kuesioner dan diprosentsikan nilainya. hasil analisis adalah sebagai berikut:

\begin{tabular}{|l|l|l|}
\hline Indikator & Jumlah & $\%$ \\
\hline STS & 1 & 0,33 \\
\hline TS & 12 & 4,00 \\
\hline RR & 86 & 28,67 \\
\hline S & 129 & 43,00 \\
\hline SS & 72 & 24,00 \\
\hline
\end{tabular}

Dari tabel di atas menunjukan respon / tanggapan yang menyatakan SETUJU sebesar $43 \%$ artinya mahasiswa menyatakan respon yang positif terhadap penerapan PjBL dengan berbantuan software SPSS. Untuk lebih jelasnya ditunjukan pula dengan grafik berikut: 


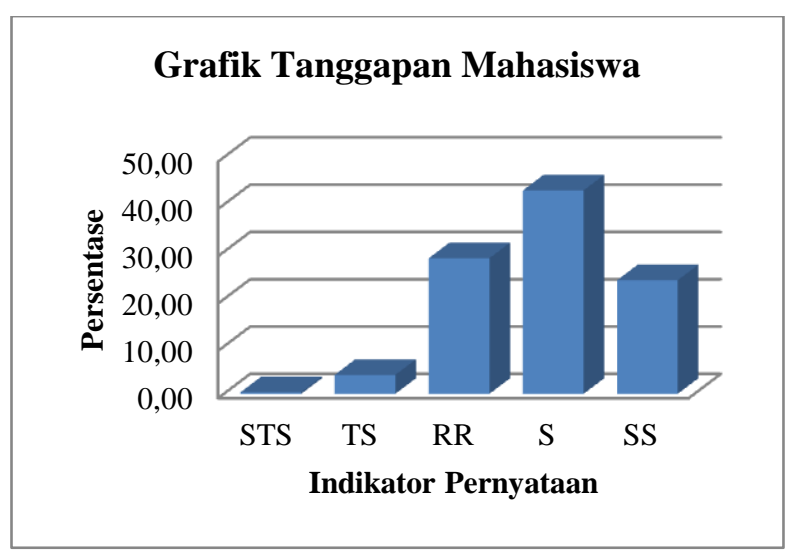

Hasil analisis regresi dipaparkan pada tabel berikut.

\begin{tabular}{|c|c|c|c|c|}
\hline No & Hipotesis & Summary & Anova & $\begin{array}{c}\text { Interpretas } \\
\mathrm{i}\end{array}$ \\
\hline 1 & $\begin{array}{l}\text { Pengaruh } \\
\text { Penerapan } \\
\text { Model } \\
\text { Pembelajaran } \\
\text { Project Based } \\
\text { Learning denga } \\
\text { n Berbantuan } \\
\text { Software SPSS } \\
\text { terhadap } \\
\text { Motivasi } \\
\text { Belajar }\end{array}$ & $\begin{array}{l}\mathrm{R}=0,922 \\
\mathrm{KD}=0,85 \\
1 \\
85,1 \%\end{array}$ & $\begin{array}{l}< \\
0,05\end{array}$ & $\begin{array}{c}\text { Ada } \\
\text { pengaruh } \\
\text { yang kuat } \\
\text { dan } \\
\text { signifikan }\end{array}$ \\
\hline 2 & $\begin{array}{l}\text { Pengaruh } \\
\text { Penerapan } \\
\text { Model } \\
\text { Pembelajaran } \\
\text { Project Based } \\
\text { Learning denga } \\
\text { n Berbantuan } \\
\text { Software SPSS } \\
\text { terhadap } \\
\text { Pemahaman } \\
\text { Statistika }\end{array}$ & $\begin{array}{l}\mathrm{R}=0,686 \\
\mathrm{KD}=0,47 \\
147,1 \%\end{array}$ & $\begin{array}{l}< \\
0,05\end{array}$ & $\begin{array}{c}\text { Ada } \\
\text { pengaruh } \\
\text { yang kuat } \\
\text { dan } \\
\text { signifikan }\end{array}$ \\
\hline 3 & $\begin{array}{l}\text { Hubungan } \\
\text { Motivasi } \\
\text { Belajar } \\
\text { terhadap } \\
\text { Pemahaman } \\
\text { Statistika }\end{array}$ & $R=0,607$ & $\begin{array}{l}< \\
0,05\end{array}$ & $\begin{array}{c}\text { Ada } \\
\text { hubungan } \\
\text { yang kuat } \\
\text { dan } \\
\text { signifikan }\end{array}$ \\
\hline 4 & $\begin{array}{l}\text { Tanggapan } \\
\text { Mahasiswa } \\
\text { terhadap } \\
\text { Penerapan } \\
\text { Model } \\
\text { Pembelajaran } \\
\quad \text { Projec } \\
t \quad \text { Based } \\
\text { Learning } \\
\text { dengan }\end{array}$ & \multicolumn{3}{|c|}{ Tangapan sebesar $43 \%$} \\
\hline
\end{tabular}

Berbantuan

Software SPSS

Dari Tabel diatas dapat diperoleh informasi bahwa penerapan model pembelajaran $\mathrm{PjBL}$ berpengaruh terhadap motivasi belajar dan pemahaman statistika mahasiswa. Selain itu, penerapan model pembelajaran PjBL ditanggapi dengan positif oleh mahasiswa.

\section{Kesimpulan}

Berdasarkan pada hipotesis, analisis data dan pembahasan yang telah dipaparkan, maka kesimpulannya adalah

1. Adanya pengaruh penerapan model pembelajaran project based learning dengan berbantuan software SPSS terhadap motivasi belajar

2. Adanya pengaruh penerapan model pembelajaran project based learning dengan berbantuan software SPSS terhadap pemahaman statistika

3. Adanya hubungan motivasi belajar terhadap pemahaman statistika

4. Adanya Tanggapan Positif dari Mahasiswa terhadap penerapan model pembelajaran project based learning dengan berbantuan software SPSS

Dari hasil penelitian yang telah dipaparkan, penulis memberikan saran sebagai berikut;

1. Bagi Lembaga, Untuk meningkatkan aktivitas proses perkuliahan hasil penelitian ini diharapkan menjadi referensi untuk meningkatkan motivasi dan projek penelitian yang sesuai dengan keilmuan teknik informasi.

2. Bagi Dosen, Untuk meningkatkan kualitas pembelajaran hasil penelitian ini dapat menjadi tolok ukur untuk diterapkan pada mata kuliah lain

3. Bagi Mahasiswa, Untuk meningkatkan kualitas akademik perlu ditanamkan motivasi agar pemahaman tentang mata kuliah yang dihadapi dapat diterapkan dalam kehidupan sehari-hari agar 
keilmuan yang dimiliki dapat berguna untuk pribadi, masyarakat dan lingkungan sekitar

Daftar Pustaka

Arikunto, S. (2002). Prosedur Penelitian. Jakarta:

Abin Syamsuddin Makmun (1998), Psikologi Kependidikan Perangkat Sistem Pengajaran Modul. Bandung: Remaja Rosdakarya

Hamzah B. Uno dan Masri Kuadrat (2009), Mengelola Kecerdasan Dalam Pembelajaran: Sebuah Konsep pembelajaran Berbasis Kecerdasan Jakarta: Bumi Aksara

Lindawati, dkk. (2013). Penerapan Model Pembelajaran Project Based Learning Untuk Meningkatkan Kreativitas Siswa Man I Kebumen (Radiasi.Vol.3.No.1). Purworejo : FKIPUniversitas Muhamadiyah Purworejo

Prabowo, A. (2012). Pembelajaran Berbasis Proyek Untuk Meningkatkan Pemahaman Mahasiswa atas Permasalahan Statistika pada Perkuliahan Studi Kasus dan Seminar. Semarang: FMIPA-UNNES Jurnal Kreano ISSN: 2086-2334 Vol.3)

Sudjana (2002). Metode Statistika. Bandung: Tarsito

Suherman,E. (2001). Strategi Pembelajaran Matematika Kontemporer.

Bandung: Universitas Pendidikan Indonesia JICA

Sugiyono, (2010). Metode Penelitian Pendidikan,

Bandung: Alfabeta.

Trianto. (2011). Mendesain Model Pembelajaran Inovatif-Progresif. Jakarta: Kencana Prenada Media Grup.

Widyantini, Th. ( 2014). Penerapan Model Pembelajaran Project Based Learning dalam Materi Pola Bilangan Kelas VII. PPPPTK. Matematika: Yogyakarta.

\section{Biodata Penulis}

Heri Herwato, memperoleh gelar Sarjana Pendidikan matematika di STKIP sebelas April Sumedang dan gelar Magister Pendidikan Matematika di Universitas

Pasundan Bandung . Saat ini menjadi Dosen di Universitas Kuningan Jawa Barat. 